\title{
The Effect of Regular Hemodialysis on the Nutritional Status of Children with End-stage Renal Disease
}

\author{
Amal Alshukri ${ }^{1 *}$, Safia Elramli², Hana M Elbakoush Lecture ${ }^{3}$, Ali Atiea Elmabsout $\mathrm{PhD}^{4}$
}

${ }^{1}$ Msc,P health stream nutrition from University of Wollongong, Australia, lecturer and Teaching staff in Nutrition department at faculity of public Health at Benghazi University

${ }^{2}$ Msc, Clinical Nutrition and Health Glasgow Caledonian University Assistant Professor, Teaching staff in Nutrition Department at faculity of public Health at Benghazi University

${ }^{3}$ Master degree from Glasgow Caledonian University In clinical nutrition and health, Teaching staff in Nutrition Department at faculity of public Health at Benghazi University

${ }^{4}$ Human nutrition, Orebro University, Sweden, Head of Nutrition Department, of the faculty of public health at the University of Benghazi, Teaching staff in Nutrition Department at faculity of public Health at Benghazi University

DOI: $10.36347 /$ sjams.2020.v08i10.038

| Received: 03.10.2020 | Accepted: 19.10.2020 | Published: 29.10.2020

*Corresponding author: Amal Alshukri

Abstract

Original Research Article

Background: Children with end-stage renal disease (ESRD) have rates of mortality estimated to be 30-times higher than expected for age compared with those of healthy children. Physical manifestations of under-nutrition, such as body mass index (BMI) have been associated with increased risk of mortality. Traditional measures, such as height, weight and serum albumin concentration, may not be accurate indicators to assess the nutritional status of children receiving maintenance hemodialysis. Meeting the special nutritional needs of these children often requires nutritional supplementation, by either the enteral or the parenteral route. Recently, in children receiving maintenance hemodialysis that is malnourished, intradialytic parenteral nutrition (IDPN) has been utilized as a means to provide additional protein and calories. Objectives: The present study was carried out to identify the malnutrition in children receiving maintenance hemodialysis, with special focus on outcome. Method: This was A cross-sectional observational study was conducted in the Department of Pediatrics of a Pediatric hospital of Benghazi from January 2019 to June 2019. 81 children aged from five to eighteen years on regular hemodialysis. Outcome measures: Measurements included questionnaire that elicited information on social demographic characteristics, Patient's medical history, and duration of hemodialysis. Anthropometry, biochemical parameters were measured. Anthropometric measurements were expressed as z - scores. Data were analyzed using descriptive statistics. The ChiSquare test was applied to examine the study data. Results: Data shows that $49.4 \%$ of children had BMI between 5 th percentile up to the 85 th percentile were considered normal weight, while, $30.9 \%$ of children had BMI less than the 5th percentile, were categorized as underweight. With regard to biochemical parameters, children had significantly higher serum phosphate, creatinine, and Blood urea nitrogen. However, study population had lower of hemoglobin and serum albumin. In addition, results show that a significant positive correlation between children who were on dialysis for 33-36months with underweight and high serum creatinine and parathyroid hormone. Conclusions: Nutritional assessment is essential to the management of children with CRF. Anthropometry is a sensitive indicator of the nutritional status.

Keywords: Nutritional status, children, nutritional assessment, anthropometric measurement, CRF, hemodialysis, ESRD

Copyright $\odot 2020$ The Author(s): This is an open-access article distributed under the terms of the Creative Commons Attribution 4.0 International License (CC BY-NC 4.0) which permits unrestricted use, distribution, and reproduction in any medium for non-commercial use provided the original author and source are credited.

\section{INTRODUCTION}

Chronic kidney disease (CKD) refers to a condition related to irreversible kidney damage that can further progress to end stage renal disease (ESRD). CKD is a major public health problem worldwide. Most of the existing data on the epidemiology of CKD during childhood concentrates on the late and more severe stages of renal impairment and are not population based in nature [1]. The incidence of CKD in Europe was consistent, being around 11- 12 per million of the age related population. The incidence rate of severe preterminal CKD in Lorraine (France) has been estimated as 7.5 per year per million of the age-related population in children younger than 16 years [2]. A number of factors influence incidence and prevalence rate of CKD variability of childhood. Factors such as racial and ethnic distribution, type of prevalent renal disease, and 
quality of medical care available for preterminal CKD patients have a significant impact on patient outcome [3]. Malnutrition [defined either by body mass index (BMI) or biochemical markers such as albumin] is a well-recognized complication and an independent risk factor for increased mortality in children with ESRD receiving maintenance HD [4]. Malnutrition is recognized to be a serious and common complication of chronic kidney disease (CKD) and is associated with increased morbidity and mortality [4]. Children with ESRD have rates of mortality approximately 30-times higher than expected forage when compared with those of healthy children. Although multiple factors might be responsible, physical manifestations of malnutrition, such as short stature, lower BMI, in the pediatric population have been demonstrated to be associated with increased risk of death [5].

Growth failure is one of the most common and profound clinical manifestation of chronic kidney disease (CKD) in infants, children and adolescents [5]. Affected children exhibit a range of potentially serious medical and psychological complications, as well as increased mortality. The etiology of growth failure in these children is multifactorial, age at onset of the disease, primary renal disease, severity of CRF, hormonal resistance; anemia, metabolic acidosis, malnutrition, renal osteodystrophy, and inadequate dialysis are all implicated [6].

Nutritional status is particularly important in children as it influences growth and sexual and neurocognitive development. Thus, its accurate and regular assessment is highly recommended in patients on regular hemodialysis (HD) [7]. Kidney disease wasting (KDW) in chronic dialysis children affects approximately one third of HD patients. Serum levels of inflammatory markers are increased, and numerous causes of chronic inflammation may be present. Hypoalbuminemia is frequently seen in patients with CKD and has been consistently shown to be associated with increased mortality in children [8]. Nutrition assessment for the monitoring of nutritional status of children on maintenance hemodialysis, the Kidney Disease Outcomes Quality Initiative (K-DOQI) recommends the following measures: dietary interview, serum albumin, height or length, estimated dry weight, mid-arm circumference, skin fold thickness, head circumference for children aged 3 years or less [9]. The pediatric renal dietician is valuable to assess and manage malnutrition in children with renal disease, and detailed guidelines exist with regard to frequency of nutrition assessment of children on maintenance hemodialysis [10]. The aim of this study is to evaluate the nutritional status in children with CRF on hemodialysis in Benghazi Pediatric Hospital.

\section{OBJECTIVES}

To assess the growth and the nutritional status in ESRD children on regular HD

To correlate their duration of dialysis with BMI and laboratory parameters

To identify how effects the duration of dialysis on BMI of HD children

\section{Materials and Methods}

This cross-sectional observational study was conducted in the Department of Pediatrics of a Pediatric hospitalof Benghazi during the period January 2019 to june 2019. The subjects of the study were childrens guests aged from five to eighteen years, who were on dialysis. The study was approved by the local Institute's Ethical Committee of Benghazi University and Pediatric hospitalof Benghazi were gave written informed consent

\section{Data Collection}

Clinical and laboratory assessment. Patient's medical history, demographics, and duration of hemodialysis were obtained from the hospital registry. None of the patients were on tube feeding or parenteral nutrition. On the day of evaluation, predialysis blood samples were collected to estimate fasting blood sugar(FBS) ,hemoglobin ,iron level, calcium ,phosphate (PO4),parathyroid hormone (PTH) ,serum creatinine, serum albumin ,blood urea nitogen ,sodium and potassium.

Anthropometric measurements were carried out 10-20 minutes after completion of hemodialysis. Full examination was carried out , including: Postdialysis body weight (in $\mathrm{kg}$ ), which coincided with the dry weight, standing height (in $\mathrm{cm}$ ) and height or length Height and body weight were measured with light clothing. Body mass index (BMI) was calculated as the ratio of end dialysis body weight in kilogram and the square of the height in meters $(\mathrm{kg} / \mathrm{m} 2)$. the patients' nutritional status was classified as follows, according to the BMI: underweight for less than the 5th percentile, healthy weight from 5th percentile up to the 85th percentile, overweight for 85 th to less than the 95 th percentile, patient has obesity, if the body mass index equals to or greater than the 95 th percentile.

\section{Statistical Analysis}

Descriptive statistics an analysis were carried out with the statistical software package SPSS21. 0). Chi -square test was processed to ascertain statistical significance between the duration of dialysis with months and Body mass index(BMI), Serum Creatinine and Parathyroid hormone. Frequency and percentage were presented for qualitative variables. 


\section{RESULTS}

Table-1: Demography, body mass index (BMI) and duration of dialysis with months of study pobpulation

\begin{tabular}{|c|c|c|c|}
\hline \multicolumn{2}{|l|}{ Charactaristes $N=(81)$} & Frequency & Percent \\
\hline \multirow{2}{*}{ sex } & Male & 52 & $64.2 \%$ \\
\hline & Female & 29 & $35.8 \%$ \\
\hline \multirow[t]{3}{*}{ Age group with years } & $3-7$ & 43 & $53.1 \%$ \\
\hline & $8-12$ & 22 & $27.2 \%$ \\
\hline & $13-17$ & 16 & $19.8 \%$ \\
\hline \multirow[t]{2}{*}{ Nationality } & libyan & 80 & $98.8 \%$ \\
\hline & Other & 1 & $1.2 \%$ \\
\hline \multirow{2}{*}{ Residency of benghazi } & Residence & 50 & $61.7 \%$ \\
\hline & None residence & 31 & $38.3 \%$ \\
\hline \multirow[t]{4}{*}{ Body mass index(BMI) } & underweight, less than the 5th percentile & 25 & $30.9 \%$ \\
\hline & healthy weight, 5th percentile up to the 85 th percentile & 40 & $49.4 \%$ \\
\hline & overweight, 85 th to less than the 95 th percentile & 8 & $9.9 \%$ \\
\hline & has obesity, equal to or greater than the 95 th percentile & 8 & $9.9 \%$ \\
\hline \multirow{9}{*}{$\begin{array}{l}\text { duration of dialysis with } \\
\text { months }\end{array}$} & $1-4$ & 20 & $24.7 \%$ \\
\hline & $5-8$ & 25 & $30.9 \%$ \\
\hline & $9-12$ & 23 & $28.4 \%$ \\
\hline & $13-16$ & 3 & $3.7 \%$ \\
\hline & $17-20$ & 1 & $1.2 \%$ \\
\hline & $21-24$ & 6 & $7.4 \%$ \\
\hline & $33-36$ & 1 & $1.2 \%$ \\
\hline & $37-40$ & 1 & $1.2 \%$ \\
\hline & $41-44$ & 1 & $1.2 \%$ \\
\hline
\end{tabular}

The final study sample included 81 patients, 64. $2 \%$ boys and $35.8 \%$ girls, with $53.1 \%$ aged of three to seven years. Approximatly $62 \%$ of patients are residence in the city of benghazi. The duration of hemodialysis ranged from one month to fourty four months (3 years and six months) with the high percentage of $30.9 \%$ for children aged from 5 to 8 years. Regarding to Body mass index (BMI), $49.4 \%$ of patients had BMI between 5th percentiles up to the 85th percentileund, which considered patients had healthy weight, furthermore $30.9 \%$ of patients had BMI less than the 5th percentile, which considered the patients had underweight.

Mean of Fasting blood sugar (FBS), iron, calcium, Parathyroid hormone (PTH), sodium and potassium levels were within normal range. Patients had significantly higher means of Phosphate (PO45. 155) $\mathrm{mg} / \mathrm{dL}$ with Standard deviation 2. 398, Serum creatinine 1. $302 \mathrm{mg} / \mathrm{dl}$ with Standard deviation1. 188, as well as, higher mean of Blood urea nitogen $37.186 \mathrm{mg} / \mathrm{dL}$ with Standard deviation25. 710. On the other hand, study population had lower means of Hemoglobin and Serum albumin.

Table-2: Laboratory parameters of study population

\begin{tabular}{|l|l|l|l|}
\hline Laboratory parameters & Mean & $\begin{array}{l}\text { Standard } \\
\text { deviation }\end{array}$ & $\begin{array}{l}\text { Normal range for } \\
\text { reference }\end{array}$ \\
\hline Fasting blood sugar(FBS) mg/dL & 105.481 & 37.061 & $7-110$ \\
\hline Hemoglobin gm/dL & 10.231 & 1.964 & $12-14$ \\
\hline Iron level gm/dL & 62.969 & 20.800 & $50-150$ \\
\hline Calcium mg/dL & 8.257 & 1.671 & $8.4-10.2$ \\
\hline Phosphate $(\mathrm{PO} 4) \mathrm{mg} / \mathrm{dL}$ & 5.155 & 2.398 & $2.4-4.1$ \\
\hline Parathyroid hormone $(\mathrm{PTH}) \mathrm{pg} / \mathrm{mL}$ & 51.850 & 25.270 & $14-65$ \\
\hline Serum creatinine $\mathrm{mg} / \mathrm{dl}$ & 1.302 & 1.188 & $1.06-0.12$ \\
\hline Serum albumin $\mathrm{g} / \mathrm{dL}$ & 2.695 & 1.249 & $3.5-4.5$ \\
\hline Blood urea nitogen $\mathrm{mg} / \mathrm{dL}$ & 37.186 & 25.710 & $5-20$ \\
\hline Sodium(Na) $\mathrm{mmol} / \mathrm{l}$ & 136.644 & 6.827 & $136-145$ \\
\hline Potassium $(\mathrm{K}) \mathrm{mmol} / \mathrm{l}$ & 5.103 & 4.215 & $3.5-5.5$ \\
\hline
\end{tabular}


Statistically significant value was reflected by the chi-square test between the duration of disease with months and the readings of Body mass index (BMI) with $\mathrm{p}$ value 0 . 005 , where $12(48 \%)$ of patients were underweight and they were on dialysis for 33-36 months. at the same side, significant $\mathrm{p}$ values of serum creatinine and parathyroid hormone were 0.006 and 0 . 00 respectivelly and the duration of disease, where 32 . $4 \%$ and $40.9 \%$ of patients who were on dialysis for $33-$ 36months

Table-3: Association between Duration of dialysis with months Body mass index (BMI), Serum Creatinine,

Parathyroid hormone (PTH)

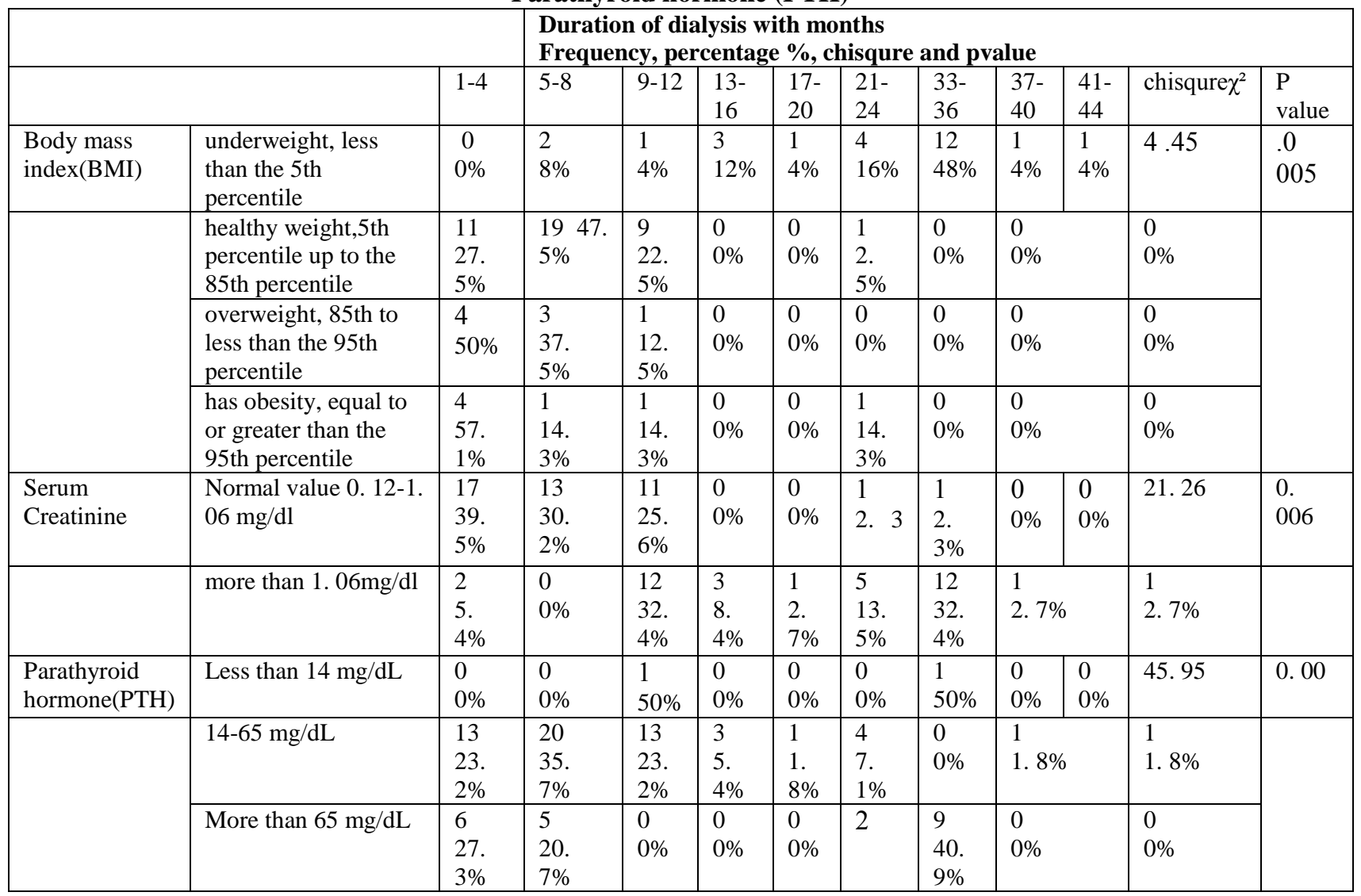

\section{DISCUSSION}

The aim of this study was to evaluate the nutritional status of $\mathrm{CRF}$ children on regular hemodialysis in Benghazi Pediatric Hospital. Assessment of the nutritional status for children receiving maintenance dialysis is extremely important. The Kidney Disease Outcome Quality Initiative (K/DOQI) Clinical Practice guidelines for Nutrition in Chronic Renal Failure (NKF-K/ DOQI, 2000) stated that no single measure provides a complete picture of nutritional status and that many different measures are recommended for assessment of the nutritional status [11]. In the present study we used BMI of children, laboratory parameters, and duration of dialysis to evaluate the nutritional status of children.

As shown in our result the duration of hemodialysis ranged from one month to forty-four months, about $30.9 \%$ of them were for children aged from 5 to 8 years. In addition the result demonstrated that $49.4 \%$ of HD children their BMI was between 5 th percentiles up to the 85 th percentile, which considered being normal, however, $30.9 \%$ of HD children their
BMI was less than 5th percentile, which appeared to be underweight as well as $9.9 \%$ of them their BMI more than $85^{\text {th }}$ and less than $95^{\text {th }}$ while the other $9.9 \%$ of children their BMI was more than $95^{\text {th }}$. Study in Egypt was done by Lotfy et al. show that the BMI of $16 \%$ of the HD children was $<5$ percentile while only $4 \%$ of the patient was 97 th percentile [12].

We also found that laboratory investigation of children appeared to be as following, sodium and potassium levels were within normal range. Patients had significantly higher means of Phosphate (PO45. 155) $\mathrm{mg} / \mathrm{dL}$ Serum creatinine $1.302 \mathrm{mg} / \mathrm{dl}$ as well as, higher mean of Blood urea nitogen 37. $186 \mathrm{mg} / \mathrm{dl}$, whereas HD children had lower means of Hemoglobin and Serum albumin. Similarity study done by Lotfy et al. illustrated that $66 \%$ of patients had hemoglobin level below $11 \mathrm{~g} / \mathrm{dL}, 70 \%$ of the patients had serum phosphorus more than $4.5 \mathrm{mg} / \mathrm{dL}$ and all the patients had blood urea nitrogen above the normal level [12]. A survey of prevalence data from the six-state New England area found that more than one third of the children with ESRD undergoing chronic HD had serum 
albumin concentrations <2. $9 \mathrm{~g} / \mathrm{dl}$ [13]. In addition Wong et al. studied 1,723 pediatric patients and found that each $1 \mathrm{~g} / \mathrm{dl}$ difference in serum albumin at the start of dialysis was associated with a 54\% higher risk of death, even after adjusting for the glomerular causes of the ESRD and other potentially confounding variables [14]. Furthermore study found that other biochemical parameters that can indirectly reflect nutritional status are hemoglobin and serum creatinine that, like total protein and serum albumin, have been found to be significantly lower in children on HD therefore children with Low serum hemoglobin and creatinine levels may need for a thorough nutritional assessment [15]. Similar to what has been found, study reported by Furth et al. [16], shows that anemia and hypoalbuminemia were associated with pediatric CKD duration. Regarding to correlation between Duration of dialysis with months Body mass index (BMI), Serum Creatinine, Parathyroid hormone (PTH. In present study, duration of dialysis showed a significant correlation with BMI. Similarly, study done by Badve et al. convinced that mean BMI decreased gradually. The average baseline BMI in the HD group was significantly related with duration of disease [17]. As well as Kotanko and colleagues observed a marked decrease in body weight in 3 months preceding HD patient. The initial decrease in BMI in the first year of starting dialysis could be due to the excess burden of illness that these patients experience at the time of reaching ESKD necessitating dialysis [18]. We also identified that hypocalcemia and hyperphosphatemia were independent risk factors for renal progression in children with CKD. Voormolen et al. [19] have previously found an association between hyperphosphatemia and a more rapid decline in renal function with disease duration (as well as mortality). About HD duration, and PTH and S. creatinine, Study was done by Barbosa et al. which does not coincide with the results. There were no differences observed between those who were below or above 36 months of treatment and PTH, S. creatinine [20]. Some other studies also found no changes of laboratorial factors (urea, creatinine, PTH (ParaThyroid Hormone) over the duration of disease which makes us think of the possibility of other factors occurring besides those investigated $[21,22]$. The limitations of the study were the small sample size; the measure of Triceps skin fold (TSF) thickness and Subscapular skin fold thickness were not taken, some of important laboratory tests were not included in the patients' medical records.

\section{CONCLUSION}

Although most ESRD patients their BMI was markedly affected. The longer the HD duration, the more severe was the effect on nutritional status of children, the growth parameters affected was BMI, serum creatinine, serum albumin, and hemoglobin. Evaluating patients frequently and regularly to maintain adequate macro- and micronutrient intake for reduction in morbidity and mortality, as well Nutrients as improvement in quality of life. A multidisciplinary team with a renal dietician may help to manage the nutritional status of CKD children. Further research regarding nutrition must be undertaken tostudy the effects of long hemodialysis duration on health outcomes for Children with End-stage Renal Disease

\section{REFERENCES}

1. Zaki ME, Hassan MM, Bazaraa HM, Ahmed HF. Nutritional status in children with chronic renal failure on hemodialysis. Macedonian Journal of Medical Sciences. 2012 Nov 1;5(3):296-301.

2. Harambat J, van Stralen KJ, Kim JJ, Tizard EJ Epidemiology of chronic kidney disease in children. Pediatr Nephrol. 2012; 27:363-73.

3. Moosa MR and Kidd M. The dangers of rationing dialysis treatment: the dilemma facing a developing country. Kidney Int. 2006; 70:1107-1114.

4. Wong CS, Gipson DS, Gillen DL, Emerson S, Koepsell T, Sherrard DJ, Watkins SL, StehmanBreen C. Anthropometric measures and risk of death in children with end-stage renal disease. Am J Kidney Dis. 2000; 36(4):811-819.

5. Morais AC, Silva MA, Faintuch J. Correlation of nutritional status and food intake in hemodialysis patients. Clinics. 2005; 60:185-92.

6. Mahan JD and Warady BA. Assessment and treatment of short stature in pediatric patients with chronic kidney disease: a consensus statement. Pediatr Nephrol. 2006; 21:917-930

7. Pupim LB, Flakoll PJ, Yu C, Ikizler TA. Recombinant human growth hormone im- proves muscle amino acid-uptake and whole body protein in chronic hemodialysis patients. Am J Clin Nutr. 2005; 82:1235-43.

8. Wong CS, Hingorani S, Gillen DL. Hypoalbuminemia and risk of death in pediatric patients with end-stage renal disease. Kidney Int 2002;61:630-7

9. Kopple JD. National kidney foundation K/DOQI clinical practice guidelines for nutrition in chronic renal failure. Am J Kidney Dis 37 [1 Suppl 2] 2001:S66-S70

10. Rees L, Shaw V. Nutrition in children with CRF and on dialysis. Pediatr Nephrol. 200722:16891702

11. National Kidney Foundation. Kidney Disease Outcome Quality Initiative (NKF-K/DOQI) Clinical practice guideline for nutrition in CRF. Am J Kidney Dis. 2000;35 (Suppl 2):S1- 40

12. Lotfy HM, Sabry SM, Ghobrial EE, Abed SA. The effect of regular hemodialysis on the nutritional status of children with end-stage renal disease. Saudi Journal of Kidney Diseases and Transplantation. 2015 Mar 1;26(2):263.

13. Brem AS, Lambert C, Hill C, Kitsen J, Shemin DG. Prevalence of protein malnutrition in children maintained on peritoneal dialysis. Pediatr Nephrol. 2002 17:527-530

14. Wong CS, Hingorani S, Gillen DL, Sherrard DJ, Watkins SL, Brandt JR, Ball A, Stehman-Breen CO 
Hypoalbuminemia and risk of death in pediatric patients with end-stage renal disease. Kidney Int. 2002 61:630-637

15. Edefonti A, Paglialonga F, Picca M A prospective multicentre study of nutritional status in children on chronic peritoneal dialysis. Nephrol Dial Transplant. 2006 21:1946-1951

16. Furth SL, Cole SR, Fadrowski JJ, Gerson A, Pierce CB, Chandra M, Weiss R, Kaskel F: The association of anemia and hypoalbuminemia with accelerated decline in GFR among adolescents with chronic kidney disease. Pediatr Nephrol. 2007; 22: 265-271.

17. Badve SV, Paul SK, Klein K, Clayton PA, Hawley CM, Brown FG, Boudville N, Polkinghorne KR, McDonald SP, Johnson DW. The association between body mass index and mortality in incident dialysis patients. PloS one. 2014 Dec 16;9(12):e114897.

18. Kotanko P, Thijssen S, Usvyat L, Tashman A, Kruse A. Temporal evolution of clinical parameters before death in dialysis patients: a new concept. Blood Purif. 2009 27:38-47.
19. Voormolen N, Noordzij M, Grootendorst DC, Beetz I, Sijpkens YW, Van Manen JG, Boeschoten EW, Huisman RM, Krediet RT, Dekker FW, PREPARE Study Group. High plasma phosphate as a risk factor for decline in renal function and mortality in pre-dialysis patients. Nephrology Dialysis Transplantation. 2007 Oct 1;22(10):290916.

20. Barbosa JB, Moura EC, Lira CL, Marinho PÉ. Quality of life and duration of hemodialysis in patients with chronic kidney disease (CKD): a cross-sectional study. Fisioterapia em Movimento. 2017 Dec;30(4):781-8.

21. Santos PR, Pontes LRSK. Mudança do nível de qualidade de vida em portadores de insuficiência renal crônica terminal durante seguimento de 12 meses. Rev Assoc Med Bras. 2007;53(4):329-34.

22. Tjaden LA, Vogelzang J, Jager KJ, van Stralen KJ, Maurice-Stam H, Grootenhuis MA. Long-term quality of life and social outcome of childhood endstage renal disease. J Pediatr. 2014;165(2);336- 